\title{
Assessing non-target effects and host feeding of the exotic parasitoid Apanteles taragamae, a potential biological control agent of the cowpea pod borer Maruca vitrata
}

\author{
Elie Ayitondji Dannon • Manuele Tamò • \\ Arnold van Huis $\cdot$ Marcel Dicke
}

Received: 12 February 2011 / Accepted: 9 October 2011/Published online: 28 October 2011

(C) The Author(s) 2011. This article is published with open access at Springerlink.com

\begin{abstract}
Apanteles taragamae Viereck is a larval parasitoid introduced in Benin for classical biological control of the cowpea pod borer Maruca vitrata Fabricius. In the laboratory, we evaluated the effects of A. taragamae on non-target herbivore species, and on another parasitoid of $M$. vitrata, i.e. the egg-larval parasitoid Phanerotoma leucobasis Kriechbaumer. Furthermore, we addressed the host feeding behaviour of A. taragamae. The host specificity of A.taragamae was assessed by offering six other lepidopteran species to the wasp. The competitive ability of A. taragamae was studied by providing the wasp with one- and twodays-old $M$. vitrata larvae that had hatched from eggs previously parasitized by $P$. leucobasis. Controls
\end{abstract}

Handling Editor: Dirk Babendreier

E. A. Dannon

Faculté des Sciences Agronomiques, Université

d'Abomey-Calavi, 01 BP 526, Cotonou, Benin

e-mail: eliedannon@yahoo.com

E. A. Dannon · A. van Huis · M. Dicke $(\square)$

Laboratory of Entomology, Wageningen University,

P.O. Box 8031, 6700EH Wageningen, The Netherlands

e-mail: marcel.dicke@wur.nl

A. van Huis

e-mail: arnold.vanhuis@wur.nl

M. Tamò

International Institute of Tropical Agriculture (IITA), Benin Station, 08 BP 0932 Tri Postal, Cotonou, Benin e-mail:m.tamo@cgiar.org consisted of eggs and larvae offered only to $P$. leucobasis and A. taragamae, respectively. None of the other six lepidopteran species was successfully parasitized by $A$. taragamae. The larval parasitoid $A$. taragamae outcompeted the egg-larval parasitoid $P$. leucobasis when offered two-days-old host larvae. Competition between the two parasitoid species did not significantly affect one-day-old host larvae that were less suitable to A. taragamae. Host feeding by $A$. taragamae did not affect survival of one-day-old or two-days-old $M$. vitrata larvae. However, the percentage parasitism of two-days-old larvae was significantly reduced when exposed to female A. taragamae wasps that had been starved during $48 \mathrm{~h}$. The data are discussed with regard to host specificity, host feeding patterns and to factors underlying the outcome of intrinsic competition between parasitoid species.

\section{Keywords Apanteles taragamae Phanerotoma leucobasis - Maruca vitrata $\cdot$ Survivorship $\cdot$ Host feeding · Intrinsic competition · Host specificity}

\section{Introduction}

The classical biological control against the cowpea pod borer Maruca vitrata Fabricius (Lepidoptera: Crambidae) has started with the introduction of the parasitoid wasp Apanteles taragamae Viereck (Hymenoptera: Braconidae) in Benin where its potential as biological control agent is being evaluated. In our 
previous studies, we have addressed the direct factors that contribute to the efficiency/suitability of the wasp. Such factors deal with the climatic adaptability of the parasitoid, its functional response, and its efficiency in searching host larvae (Dannon et al. 2010a, b). However, some indirect or additional attributes might require particular attention with regard to the environmental risks of introduced species. Main areas of concern include host specificity, competitive ability and host-feeding behaviour (van Lenteren et al. 2003; Stiling and Cornelissen 2005).

The effects of a biological agent on non-target herbivore species depend on its degree of specialization (Henneman and Memmott 2001; Symondson et al. 2002; Louda et al. 2003). A strictly specialist parasitoid may not affect non-target herbivore species. A relative specialist parasitoid that has a narrow host range is expected to have a limited environmental risk, while a generalist is expected to affect non-target hosts (Henneman and Memmott 2001; Symondson et al. 2002; Louda et al. 2003; van Lenteren et al. 2003). The host range of a parasitoid can be viewed physiologically or ecologically (Louda et al. 2003; Babendreier et al. 2003, 2005; Haye et al. 2005).

Competition affects the dynamics of ecological communities and may be intra- or inter-specific (Birch 1957). Inter-specific or heterospecific competition is found to be an important factor that influences the outcome of biological control (Pijls et al. 1995; de Moraes et al. 1999; Ngi-Song et al. 2001; van Lenteren et al. 2003; Boivin and Brodeur 2006). Therefore, the competitive ability should be considered when selecting a biological control agent (de Moraes et al. 1999). The outcome of the competition depends on several factors and different mechanisms have evolved in competitors within multi-parasitized hosts (Fisher 1961; Vinson and Iwantsch 1980; Collier and Hunter 2001; de Moraes and Mescher 2005; Yamamoto et al. 2007). Mechanisms involve physical attack and physiological suppression of the less competitive species (Fisher 1961; Vinson and Iwantsch 1980; McBrein and Mackauer 1990; de Moraes et al. 1999).

Host feeding is reported to influence the performance in some parasitoid species (Jervis and Kidd 1986). Hymenopteran parasitoid females are known to feed on host haemolymph and tissue during oviposition. Several host feeding patterns have been reported (Benson 1973; Hagstrum and Smittle 1978).
According to Jervis and Kidd (1986), four types of host feeding can be distinguished: concurrent, nonconcurrent, destructive and non-destructive. Concurrent host feeding means that the female parasitoid uses the same host individual for both feeding and oviposition, while non-concurrent means that different hosts are used. In destructive host feeding the host dies, while in non-destructive host feeding the host survives. Parasitoid species have been reported to combine these different types (Krrivan 1997). Of all the feeding types, the non-concurrent and destructive or concurrent and non-destructive types were found to maximize parasitoid fitness (Křivan 1997).

The current study addresses the parasitoid $A$. taragamae. This parasitoid wasp has been reported to parasitize only $M$. vitrata in Taiwan, from where it has been exported to Benin (Huang et al. 2003). However, some reports about the same species in India indicated that it parasitized five other Pyraloidea species (Peter and David 1992; Mohan and Sathiamma 2007). Of these species, only Corcyra cephalonica Stainton (Lepidoptera: Pyralidae) occurs in Benin. Moreover, the parasitoid species from Taiwan was strictly solitary while that from India was reported to be gregarious. For that reason, the latter species is likely to be different from the one imported from Taiwan into Benin. The current Apanteles species ( $A$. taragamae) was identified at the International Institute of Entomology, UK in collaboration with Taiwan Agricultural Research Institute and the World Vegetable Center (AVRDC) (Huang et al. 2003).

In the study presented here, the following attributes of the biology of $A$. taragamae have been addressed: host specificity, competitive capacity and host feeding behaviour. A number of non-target insect species was selected based on the main criteria often used to assess the host range of classical biological control agents (Kuhlmann et al. 2006; van Lenteren et al. 2006; Parry 2009). The competitive capacity of A. taragamae was evaluated in comparison with the dominant parasitoid species occurring in Benin, Phanerotoma leucobasis Kriechbaumer (Hymenoptera: Braconidae) (Arodokoun et al. 2006). This egg-larval parasitoid accounted for less than $6 \%$ of $M$. vitrata overall parasitism, as recorded on cowpea (Arodokoun et al. 2006). The biological characteristics of A. taragamae that we addressed here are of major consideration when selecting an effective biological control agent. 


\section{Materials and methods}

Insect species

\section{Maruca vitrata}

A colony of $M$. vitrata was established in the laboratory from samples collected in cowpea fields at IITA Benin and reared for 50 generations. Pupae of $M$. vitrata obtained from this culture were placed in open Petri dishes. They were incubated in wooden cages $(44 \times 45 \times 58 \mathrm{~cm})$ with sleeves, having sides of fine mesh and a glass top, at $27.0 \pm 0.6^{\circ} \mathrm{C}$ and $60.9 \pm 4.6 \% \mathrm{RH}$ (mean $\pm \mathrm{SD}$ ). Emerging adults were fed using cotton fibres moistened with $10 \%$ glucose solution. Four-days-old female moths were transferred in groups of four or five individuals to transparent cylindrical plastic cups $(3 \mathrm{~cm}$ diameter $\times 3.5 \mathrm{~cm}$ height) and kept for $24 \mathrm{~h}$ to allow for oviposition, which occurred on the inner surface of the cups. Ovipositing females were fed using small pieces of filter paper moistened with $10 \%$ glucose solution, which were replaced every $24 \mathrm{~h}$. Cups carrying eggs were kept at the same experimental conditions until the larvae hatched. Larvae were transferred to large cylindrical plastic containers $(9 \mathrm{~cm}$ diameter $\times 12 \mathrm{~cm}$ height) provided with artificial diet prepared according to Jackai and Raulston (1988), and reared until pupation. Pupae were collected and placed in cages until adult emergence. Maruca vitrata eggs used in the different experiments were obtained from this mass production.

\section{Non-target insect species}

The determination of parasitoid host range is considered to be an indicator of non-target risks (van Lenteren et al. 2006). Several factors are often used to select non-target organisms to be investigated (Kuhlmann et al. 2006; Parry 2009). Of these, phylogenetic similarities, ecological similarities, availability and socioeconomic factors have been used to select the following species for assessing the physiological host range of A. taragamae:

- the African sugar-cane borer [Eldana saccharina Walker (Lepidoptera: Pyralidae)],

- the spotted stalk borer [Chilo partellus (Swinhoe) (Lepidoptera: Crambidae)],
- the ear-borer [Mussidia nigrivenella Ragonot (Lepidoptera: Pyralidae)],

- the false codling moth [Cryptophlebia leucotreta (Meyrick) (Lepidoptera: Tortricidae)],

- the cotton leaf-roller [Sylepta derogata Fabricius (Lepidoptera: Pyralidae)],

- the rice moth [Corcyra cephalonica Stainton (Lepidoptera: Pyralidae)].

All six species belong to the order Lepidoptera. Five of them belong to the superfamily Pyraloidea and one to the family Tortricidae. They are all borers with the exception of $S$. derogata that is a leaf-roller. This species was reported to be parasitized by an Apanteles species (Odebiyi 1982). All six species occur in Benin ecosystems, are pests of economically important plants such as maize and cotton, and could be collected from the field for culturing in the laboratory. They were selected based on information obtained from the literature and the museum collection of the IITA, Benin station. Besides the species M. vitrata, the genus Maruca contains other species such as e.g. Maruca amboinalis occurring in the area of origin of $M$. vitrata, i.e. Indo-Malaysia (M Tamò, personal observation). However, none of these species is present in Benin. For these reasons, economically important Pyraloidea species occurring in Benin were considered in combination with ecological similarities for this first attempt to determine the physiological host range of A. taragamae with regard to its non-target effects in Benin. Colonies of the six lepidopteran species were established from samples taken in different areas of Benin. Larvae of E. saccharina and $S$. derogata were initially collected from maize and cotton fields at the IITA Benin station, respectively. Colonies of $M$. nigrivenella and $C$. leucotreta were obtained from maize cobs stored at IITA Benin. Larvae of $C$. partellus were sampled in rice fields at Ouedeme, $120 \mathrm{~km}$ West of Cotonou. The initial colony of $C$. cephalonica was obtained from a stock culture at IITA Benin. Maize stems, collected from maize fields grown at the IITA Benin station, were used to feed larvae of E. saccharina and C. partellus, while larvae of $M$. nigrivenella and $C$. leucotreta were fed using young maize cobs. Cotton leaves collected from a cotton field at the IITA Benin station were used to feed larvae of S. derogata. Larvae of C. cephalonica were reared on millet grains bought from local markets in Northern Benin. 


\section{Phanerotoma leucobasis}

A colony of the egg-larval parasitoid P. leucobasis Kriechbaumer was established from cocoons obtained from Lonchocarpus sericeus flowers, collected at Sehoue, $90 \mathrm{~km}$ North of Cotonou. At emergence, males and females were kept together for mating. Mated females were transferred to small cups containing $M$. vitrata eggs for parasitization. Parasitized larvae were provided with artificial diet (see above) until pupation. Adult parasitoids obtained from this mass rearing were used in this study.

\section{Apanteles taragamae}

Cocoons of A. taragamae collected from Sesbania cannabina (Retz.) Pers. fields in Taiwan were used to establish the parasitoid colonies at the laboratory of the IITA Benin. At the time of this study, the parasitoid had been reared for about 60 generations since its introduction in 2005. Cocoons obtained from this stock culture, were kept in plastic cylindrical cups $(4.5 \mathrm{~cm}$ diameter $\times 5 \mathrm{~cm}$ height $)$ till adult emergence. A hole ( $2 \mathrm{~cm}$ diameter) punched in the lid of the cups was covered with fine mesh. Adults of $A$. taragamae were fed with honey streaked on the fine mesh of the lid. To allow mated female wasps to parasitize hosts, they were offered, during $24 \mathrm{~h}$, twodays-old larvae of $M$. vitrata in a small cylindrical cup (3 cm diameter $\times 3.5 \mathrm{~cm}$ height) containing a piece of artificial diet. The parasitized larvae were reared until the cocoon stage. Cocoons were collected and placed in cylindrical cups $(4.5 \mathrm{~cm}$ diameter $\times 5 \mathrm{~cm}$ height). The mass production of wasps took place in a climate chamber with a temperature of $25.3 \pm 0.5^{\circ} \mathrm{C}$ and a RH of $78.9 \pm 5.6 \%$ (mean $\pm \mathrm{SD}$ ).

Experiment 1: physiological host range of A. taragamae

No-choice tests in small-scale arenas were suggested to be carried out for determining the acceptability and suitability of non-target species by a parasitoid (van Lenteren at al. 2003, 2006; Haye et al. 2005). In nochoice tests, target and non-target organisms are offered to the parasitoid in different sequences to avoid the effect of the parasitoid's physiological state (van Lenteren et al. 2003). When a non-target species is successfully parasitized, small-arena behavioural choice tests should be performed to assess the parasitoid preference. The test stops when none of the nontarget species is successfully parasitized (van Lenteren et al. 2003, 2006). Based on these recommendations we have carried out the following experiment.

Naïve three-days-old mated females of A. taragamae were individually placed into plastic cups $(9 \mathrm{~cm}$ diameter $\times 12 \mathrm{~cm}$ height), each containing one larva (one-, two- or three-days-old) of M. vitrata. The parasitoid was observed until it inserted its ovipositor in the larva which was then assumed to be parasitized. When the larva was parasitized, the female wasp was removed, kept for $24 \mathrm{~h}$ and used to parasitize a larva of one of the six pyraloid species: C. partellus, E. saccharina, M. nigrivenella, C. cephalonica, C. leucotreta, and $S$. derogata. When the larva was not stung within $10 \mathrm{~min}$, the wasp was discarded and replaced by another female. Another $24 \mathrm{~h}$ later, the experiment was repeated with the same female wasp, offering again a larva of $M$. vitrata for parasitization. Then, the wasp was discarded. Larvae of one-, two- and threedays-old were studied separately in different trials for each of the non-target insect species. Parasitized larvae were reared on artificial diet until pupation at $25.3 \pm 0.5^{\circ} \mathrm{C}$ and $78.9 \pm 5.6 \% \mathrm{RH}$ (mean $\pm \mathrm{SD}$ ). A positive control experiment was run for the three days using only larvae of $M$. vitrata. Experiments were conducted at $25.3^{\circ} \mathrm{C}$ because previous studies had shown that the optimum temperature for A. taragamae development ranges between $24^{\circ} \mathrm{C}$ and $26^{\circ} \mathrm{C}$ (Dannon et al. 2010a).

In a second trial, naïve female parasitoids were offered a one-, two- or three-days-old larva of one of the non-target species. The following day, the same female wasp was placed in a plastic cup containing a single one-, two- or three-days-old larva of $M$. vitrata. This experiment was repeated ten times using different female wasps for each of the non-target host species.

In a third trial, A. taragamae was allowed during $24 \mathrm{~h}$ to parasitize ten larvae of each of the non-target species, jointly placed in cups $(9 \mathrm{~cm}$ diameter $\times 12 \mathrm{~cm}$ height). One three-days-old mated female was released in each cup. A total of five females (with ten larvae per female) were used for each non-target species. Larvae were reared until the pupal stage, by using maize stem portions for the stem borers (E. saccharina, C. partellus), maize cobs for 
M. nigrivenella and C. leucotreta, millet grains for C. cephalonica, and cotton leaves for S. derogata.

Experiment 2: interspecific competition between A. taragamae and P. leucobasis

\section{Development time of the parasitoids}

Two naïve three-days-old mated females of $P$. leucobasis were introduced into cups $(3 \mathrm{~cm}$ diameter $\times 3.5 \mathrm{~cm}$ height) containing on average $25 \mathrm{M}$. vitrata eggs. Parasitization was observed visually until all eggs were stung by female wasps. Stung eggs (assumed to be parasitized) were kept until hatching. Hatched larvae were individually placed in cups $(3 \mathrm{~cm}$ diameter $\times 3.5 \mathrm{~cm}$ height) provided with a piece of artificial diet and reared until pupation. Cocoons were kept until adult emergence. Development time was recorded for each stage. Experiments were carried out in a climate chamber at $25.3 \pm 0.5^{\circ} \mathrm{C}$ and a $\mathrm{RH}$ of $78.9 \pm 5.6 \%$ (mean $\pm \mathrm{SD}$ ).

The development time of the larval parasitoid $A$. taragamae was also determined using similar experimental conditions. Two-days-old host larvae were offered to three-days-old mated female parasitoids. Two female wasps were released in cups containing on average 20 host larvae. The parasitoids were observed until they inserted their ovipositor in a larva which was then assumed to be parasitized. Larvae were individually transferred into cups $(3 \mathrm{~cm}$ diameter $\times 3.5 \mathrm{~cm}$ height) as soon as they were parasitized and were reared on artificial diet until cocoon stage. Cocoons were collected and kept till adult emergence. The development time from larval age to cocoon, and from cocoon to adult emergence was noted. A total of 100 parasitized eggs or larvae were reared per parasitoid species.

\section{Sequential no-choice tests}

The outcome of the intrinsic competition between $P$. leucobasis and A. taragamae was assessed using oneand two-days-old larvae. Larvae hatching from eggs parasitized by $P$. leucobasis, were submitted to parasitization by A. taragamae at the ages of one and two days. Female $A$. taragamae were individually released in cups $(3 \mathrm{~cm}$ diameter $\times 3.5 \mathrm{~cm}$ height) containing $20 \mathrm{P}$. leucobasis-parasitized larvae and kept for $24 \mathrm{~h}$ to allow for oviposition by A. taragamae. Larvae were then reared on artificial diet until pupation. The number of cocoons obtained per parasitoid species for each larval age was recorded. In parallel, we reared as control $M$. vitrata larvae that hatched from eggs parasitized by $P$. leucobasis, and those that were parasitized only by A. taragamae. Experiments were replicated five times with 20 larvae per replicate for one-day-old larvae (100 larvae in total) and ten times with 20 larvae per replicate for twodays-old larvae (200 larvae in total). Experiments on the competition between the braconids were performed with only one and two-days-old larvae because A. taragamae was reported to be unable to parasitize larvae older than three days (Dannon et al. 2010a).

Experiment 3: influence of adult wasps' host feeding on larval survival and parasitism rates

The influence of host feeding of A. taragamae females on larval survival was investigated using one- and two-days-old larvae. Ten larvae of each age were placed in cups $(3 \mathrm{~cm}$ diameter $\times 3.5 \mathrm{~cm}$ height $)$ containing artificial diet. One couple of 24 or $48 \mathrm{~h}$ food-deprived wasps was released in each cup to allow larval parasitization. In parallel, honey-fed couples of wasps were released in other cups containing ten larvae of each age. Control larvae consisted of $M$. vitrata larvae that were not submitted to parasitization by A. taragamae. Experiments were replicated five times with ten larvae per replicate for each larval age (50 larvae in total). Larval mortality was recorded daily until cocoon stage.

\section{Statistical analysis}

The development time of the two parasitoid species was compared using a $t$ test. The percentage parasitism of one- or two-days-old larvae for each parasitoid species in competition or alone, and larval survival or effect of host feeding on percentage parasitism of $A$. taragamae were analyzed using the General Linear Model procedure of SAS followed by a Tukey test for the separation of means. A $t$ test was used to compare separately for each parasitoid species the percentage parasitism with or without competition per larval age. Percentage data $(\mathrm{p})$ was arcsine $\sqrt{ }(\mathrm{p} / 100)$ transformed prior to statistical tests. 


\section{Results}

Physiological host range of $A$. taragamae

Although A. taragamae successfully parasitizes and develops in $M$. vitrata larvae, none of the other six lepidopteran species was successfully parasitized by A. taragamae. Visual observation of wasp behaviour revealed that females did not explore the larvae of five non-host species at all, namely $C$. partellus, $M$. nigrivenella, S. derogata, C. leucotreta, C. cephalonica. Only larvae of $E$. saccharina were probed during random runs but without an effective parasitization, even when female wasps were kept together with larvae for $24 \mathrm{~h}$ to allow for oviposition.

Development time of $P$. leucobasis

and A. taragamae

The development time from egg to cocoon of the egglarval parasitoid $P$. leucobasis was twice as long as that of the larval parasitoid A. taragamae $(\mathrm{t}=62.19$; $\mathrm{df}=130 ; P<0.0001)$. The cocoon stage was also longer but only by 0.6 days $(\mathrm{t}=7.44 ; \mathrm{df}=88$; $P<0.0001$ ) (Table 1). The complete cycle from egg to adult for A. taragamae (12.2 days) was 7.5 days shorter when compared to that of $P$. leucobasis $(\mathrm{t}=72.48 ; \mathrm{df}=88 ; P<0.0001)$.

Influence of inter-specific competition with $P$. leucobasis on the percentage parasitism of one- or two-days-old M. vitrata larvae

by A. taragamae

The percentage parasitism was calculated for each parasitoid species in competition with the other species or in the absence of competition considering two M. vitrata larval ages, i.e. one- (Fig. 1) or twodays-old larvae (Fig. 2).
When one-day-old $P$. leucobasis-parasitized larvae were offered to A. taragamae the parasitization success of $P$. leucobasis was slightly, but not significantly, reduced compared to that obtained in the absence of competition (Fig. 1). Likewise, the percentage of one-day-old larvae parasitized by $A$. taragamae did not show any significant differences in competition or in the absence of competition (Fig. 1). However, the parasitization success of $P$. leucobasis was significantly higher than that of $A$. taragamae in one-day-old larvae $(\mathrm{F}=11.66 ; \mathrm{df}=3$, $12 ; P=0.0007)$.

The percentage parasitism of two-days-old $P$. leucobasis-parasitized larvae by $A$. taragamae did not differ significantly from that obtained when $A$. taragamae was offered unparasitized $M$. vitrata larvae (Fig. 2). But the percentage parasitism of two-daysold larvae (Fig. 2) by A. taragamae was at least three times higher than that of one-day-old larvae (Fig. 1) when larvae were offered only to this parasitoid $(\mathrm{t}=3.84 ; \mathrm{df}=13 ; P=0.002)$. On the other hand, the parasitization success of $P$. leucobasis was significantly lower in competition (when two-days-old $P$. leucobasis-parasitized larvae were offered to $A$. taragamae) compared to that observed when $M$. vitrata eggs were submitted only to $P$. leucobasis (Fig. 2) $(\mathrm{F}=12.94 ; \mathrm{df}=3,27 ; P<0.0001)$. No significant differences were found between the percentage parasitism on one- (Fig. 1) and two-days-old (Fig. 2) larvae when $M$. vitrata eggs were offered to $P$. leucobasis only $(\mathrm{t}=0.43$; $\mathrm{df}=13 ; P=0.67)$.

Influence of adult wasps host feeding on larval survival and parasitism rates

Direct behavioural observations revealed that starved females of A. taragamae inserted their mandibles in host larvae and might feed on them. Host feeding by the parasitoid A. taragamae did not significantly affect

Table 1 Development time of the egg-larval parasitoid P. leucobasis and the larval parasitoid A. taragamae in $M$. vitrata at $25^{\circ} \mathrm{C}$

\begin{tabular}{lllr}
\hline Parasitoid species & \multicolumn{2}{l}{ Development time \pm SE (days) } & \\
\cline { 2 - 4 } & Egg-cocoon & Cocoon-adult & Egg-adult (cycle) \\
\hline A. taragamae & $7.42 \pm 0.06(70) \mathrm{a}$ & $4.97 \pm 0.06(40) \mathrm{a}$ & $12.18 \pm 0.06(40) \mathrm{a}$ \\
P. leucobasis & $14.29 \pm 0.05(62) \mathrm{b}$ & $5.56 \pm 0.08(50) \mathrm{b}$ & $19.74 \pm 0.08(40) \mathrm{b}$ \\
\hline
\end{tabular}

Numbers in parentheses are the number of replicates

Means followed by the same letter in each column are not significantly different ( $t$ test, $\alpha=0.05$ ) 


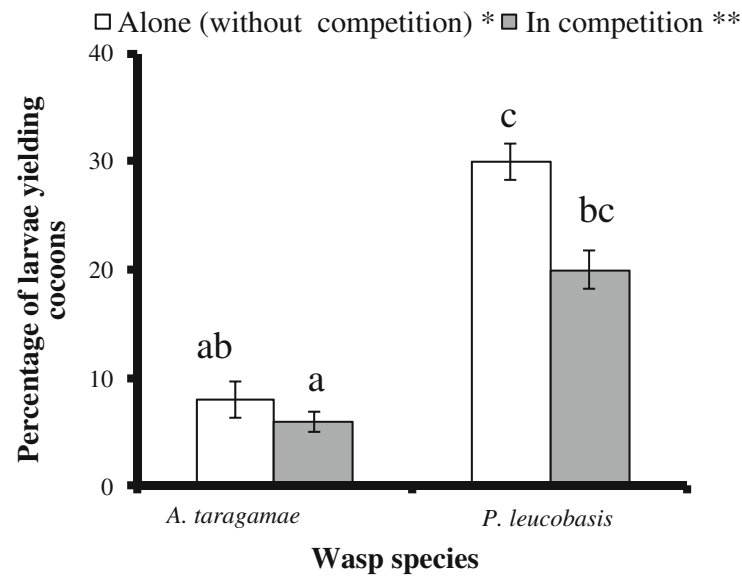

Fig. 1 Parasitization success (cocoons \pm SE) of P. leucobasis and $A$. taragamae when one-day-old $P$. leucobasis-parasitized or non-parasitized larvae were offered to A. taragamae either in competition or without competition. *Alone (without competition) refers to the experiment where eggs of $M$. vitrata were parasitized by $P$. leucobasis only or where larvae of $M$. vitrata were parasitized by $A$. taragamae only. **In competition refers to the experiment where larvae hatched from $M$. vitrata eggs parasitized by $P$. leucobasis were subsequently offered to $A$. taragamae, Means are on five replications, each with 20 larvae. Means followed by the same letter are not significantly different (ANOVA, followed by Tukey test, $\alpha=0.05$ )

the survival of $M$. vitrata larvae when one-day-old larvae were exposed to $24 \mathrm{~h}$-starved parasitoid females $(\mathrm{F}=0.31 ; \mathrm{df}=2,8 ; P=0.74$ ) (Fig. 3). Similarly, there were no significant differences in larval survival when two-days-old larvae were exposed to $24 \mathrm{~h}(\mathrm{~F}=0.22 ; \mathrm{df}=2,8 ; P=0.8)$ or 48 h-starved females $(\mathrm{F}=0.62 ; \mathrm{df}=2,8 ; P=0.6)$ in comparison with honey-fed ones (Fig. 4). Only $20 \%$ of the starved wasp couples survived beyond $48 \mathrm{~h}$. No significant differences were obtained between $24 \mathrm{~h}$ starved and honey-fed female wasps for their ability to parasitize two-days-old larvae of M. vitrata (Fig. 5). However, $48 \mathrm{~h}$ of starvation drastically reduced the percentage parasitism by $A$. taragamae $(\mathrm{F}=4.22$; df $=3,12 ; P=0.03$ ) (Fig. 5).

\section{Discussion}

\section{Physiological host range}

The parasitoid wasp A. taragamae displayed a strict specificity to $M$. vitrata when offered six other

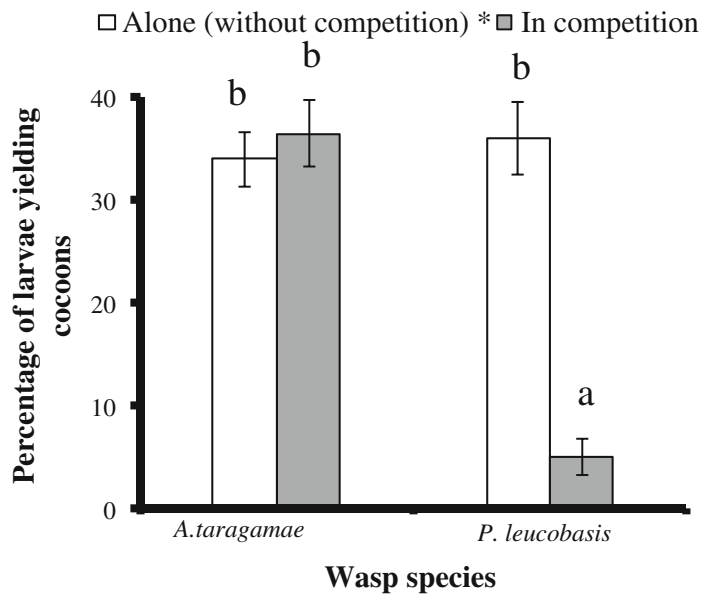

Fig. 2 Parasitization success (cocoons \pm SE) of P. leucobasis and $A$. taragamae when two-days-old $P$. leucobasis-parasitized or non-parasitized larvae of $M$. vitrata were offered to $A$. taragamae either in competition or without competition. *Alone (without competition) refers to the experiment where eggs of $M$. vitrata were parasitized by $P$. leucobasis only or where larvae of M. vitrata were parasitized by $A$. taragamae only. **In competition refers to the experiment where larvae hatched from $M$. vitrata eggs parasitized by $P$. leucobasis were subsequently offered to A. taragamae, Means are on ten replications, each with 20 larvae. Means followed by the same letter are not significantly different (ANOVA, followed by Tukey test, $\alpha=0.05)$

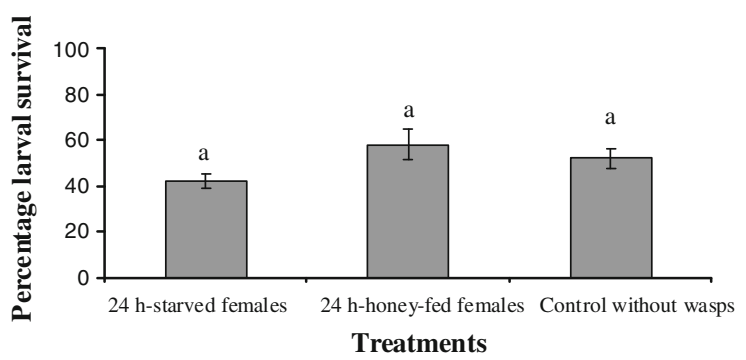

Fig. 3 The survival rate $( \pm \mathrm{SE})$ of one-day-old $M$. vitrata larvae parasitized or not by $24 \mathrm{~h}$-starved or honey-fed females of $A$. taragamae. Control without wasps consists of larvae of $M$. vitrata that were not parasitized by A. taragamae. Means are on five replications, each with ten larvae. Means followed by the same letter are not significantly different (ANOVA followed by Tukey test, $\alpha=0.05$ )

lepidopteran species. Most of the selected species were reported to damage either maize, cotton, or millet, and these crops often share the same agroecosystem with cowpea. Host suitability to parasitoid development depends on many factors including environmental influences, parasitoid ability to evade the host's internal defense system, competition with 

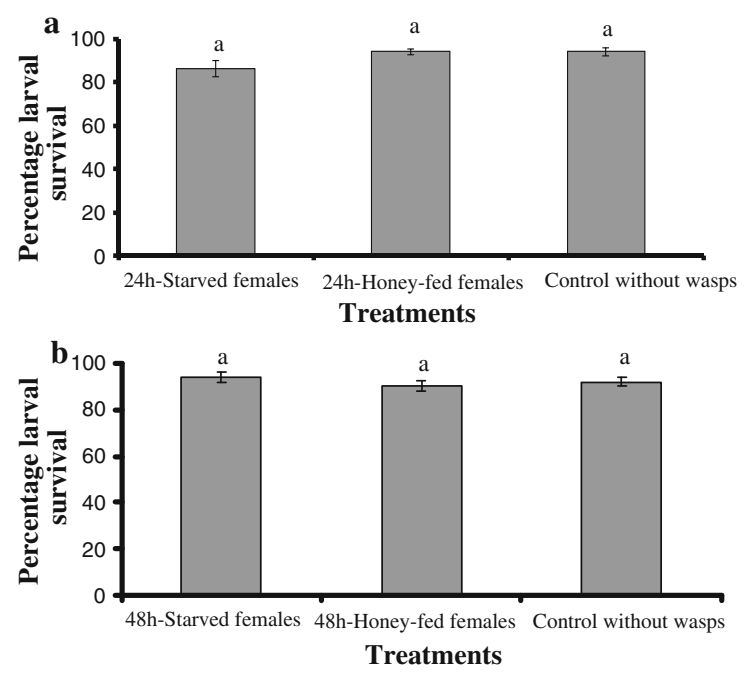

Fig. 4 The survival rate $( \pm \mathrm{SE})$ of two-days-old $M$. vitrata larvae parasitized or not by $24 \mathrm{~h}$-starved or $24 \mathrm{~h}$-honey-fed (a) and $48 \mathrm{~h}$-starved or $48 \mathrm{~h}$-honey-fed females of A. taragamae (b). Control without wasps consists of larvae of $M$. vitrata that were not parasitized by A. taragamae. Means are on five replications, each with ten larvae. Means followed by the same letter were not significantly different (ANOVA followed by Tukey test, $\alpha=0.05$ )

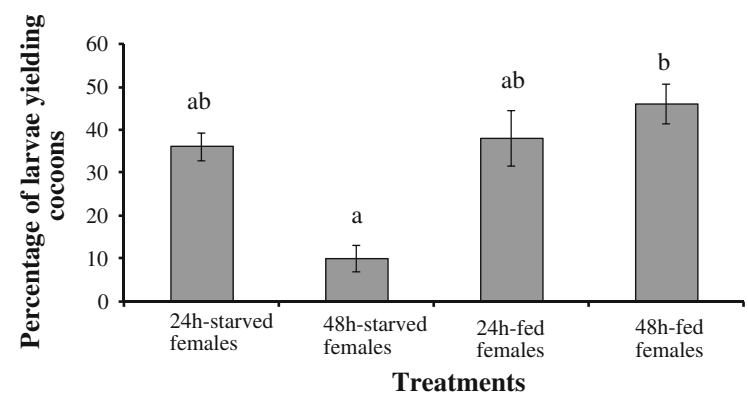

Fig. 5 Percentage parasitism ( $\pm \mathrm{SE}$ ) of two-days-old $M$. vitrata larvae by 24 or $48 \mathrm{~h}$-starved and honey-fed females of $A$. taragamae. Means are on five replications, each with ten larvae. Means followed by the same letter were not significantly different (ANOVA followed by Tukey test, $\alpha=0.05$ )

other parasitoids, presence of toxins detrimental to the parasitoid eggs or larvae, and host nutritional adequacy (Vinson and Iwantsch 1980). Host specificity has often been reported for Apanteles species (NgiSong et al. 1999). However, some reports about $A$. taragamae indicated that it parasitized five other Pyraloidea species in India (Peter and David 1992; Mohan and Sathiamma 2007). Of these reported hosts, only one, i.e. C. cephalonica, occurs in Benin.
However, it was not parasitized by the wasp in our study. For this reason, we tend to believe that $A$. taragamae reported from India is likely to be a different species from the one we have received from Taiwan. Also, the species from India is reported as being gregarious (Peter and David 1992), while the species we have obtained from Taiwan is strictly solitary (Huang et al. 2003; Dannon et al., unpublished data).

Competition between the parasitoids A. taragamae and P. leucobasis

Community dynamics depends partly on the outcome of competition among species and may affect the management of herbivorous insect pests in tritrophic systems. The outcome of the competition between different parasitoid species sharing the same host is known to be affected by several factors (McBrein and Mackauer 1990; de Moraes et al. 1999; Collier and Hunter 2001; Collier et al. 2002; Pérez-Lachaud et al. 2002; de Moraes and Mescher 2005; Yamamoto et al. 2007). Of these, development time of the parasitoids from egg to adult stage, oviposition order between parasitoid species, development stage of the host when it is parasitized, and larval morphology of the different competitors are of importance (McBrein and Mackauer 1990; de Moraes et al. 1999; de Moraes and Mescher 2005; Yamamoto et al. 2007). In the present study, the egg-larval parasitoid P. leucobasis was the first to oviposit in M. vitrata eggs. Its development time from egg to cocoon was longer than that of the larval parasitoid A. taragamae, which may explain why the latter outcompeted $P$. leucobasis. In competition, the parasitization success of the egg-larval parasitoid $P$. leucobasis was significantly reduced compared to that obtained for the control (in the absence of competition). When offered one- or twodays-old larvae, the percentage parasitism of the larval parasitoid A. taragamae was not significantly affected by previous parasitization by $P$. leucobasis in comparison with the control. However, the percentage parasitism for A. taragamae in one-day-old larvae was significantly lower than that obtained with two-daysold larvae. This may be due to differential host suitability. These findings concur with those of Dannon et al. (2010a) who reported that one-day-old larvae were less suitable to A. taragamae development than two-days-old larvae. Differences observed in the 
development time of the two parasitoid species may affect the outcome of their competition. Because the development time of $P$. leucobasis from egg to cocoon stage is longer than that of A. taragamae (Table 1), we hypothesize that the eggs of the latter hatch earlier. Therefore, larvae of A. taragamae might win the intrinsic competition with $P$. leucobasis by developing different mechanisms such as physical or physiological attacks. Indeed, in competition, larvae of some parasitoids are known to outcompete their competitors through direct physical or physiological attacks (Fisher 1961; Vinson and Iwantsch 1980; Laing and Corrigan 1987; McBrein and Mackauer 1990; de Moraes et al. 1999; Muturi et al. 2006). The present study did not investigate the mechanisms involved in the intrinsic competition between A. taragamae and $P$. leucobasis. Results from these simplified experiments cannot be extrapolated to field conditions nor used to accurately predict the overall outcome of the competition between the two parasitoid species. Previous studies showed that the percentage parasitism of $A$. taragamae increased with host density but the wasp was not able to parasitize all offered host larvae even in a small arena (Dannon et al. 2010a). Therefore, in heterogeneous and complex natural environments, a fraction of larvae may remain unparasitized. Thus, a spatio-temporal niche partitioning or dispersal-competition trade-off may lead to the coexistence of the two parasitoid species with optimum control of $M$. vitrata through complementary action. Indeed, previous studies revealed that $P$. leucobasis was found mostly on trees that are host plants of $M$. vitrata such as Pterocarpus santalinoides and L. sericeus (Tamò et al. 2002; Arodokoun et al. 2006), while $A$. taragamae was abundant on a shrub host plant Sesbania cannabina in Taiwan (its origin) (Huang et al. 2003). This preference of A. taragamae for $M$. vitrata host plants with lower growth habit might lead to niche partitioning, thus contributing to the coexistence of A. taragamae with P. leucobasis.

Influence of parasitoid host feeding on larval survival and parasitism rates

Host feeding behaviour has been reported for some braconid species (Jervis and Kidd 1986). In this study, feeding by starved A. taragamae on one- or two-daysold $M$. vitrata did not significantly reduce the survival of host larvae when compared with control treatments exposed to honey-fed female parasitoids. Based on this observation, we conclude that $A$. taragamae displays a non-destructive host-feeding pattern (Jervis and Kidd 1986). The fact that no significant differences were observed between $24 \mathrm{~h}$-starved and honey-fed females for the percentage parasitism of two-days-old larvae suggests a concurrent host feeding by A. taragamae ovipositing females. The maximum duration of food deprivation tolerated by $A$. taragame is $48 \mathrm{~h}$, and only $20 \%$ of the wasps survived after $48 \mathrm{~h}$ of starving, indicating that feeding on host larvae did not provide the parasitoid all required nutrients for its survival. However, no significant differences were observed between $24 \mathrm{~h}$-starved and honey-fed females for their ability to parasitize $M$. vitrata larvae. This supports the notion that in pro-ovigenic parasitoids such as $A$. taragamae (Dannon et al., unpublished data), host feeding does not improve reproductive output (Fellowes et al. 2005). Indeed, host feeding during oviposition provides materials for somatic maintenance in proovigenic parasitoids, while it supplies the synovigenic ones in materials necessary for continued egg maturation (Chan and Godfray 1993; Fellowes et al. 2005).

This study evaluated some indirect or additional biological characteristics that influence the efficiency of the parasitoid wasp A. taragamae, a potential biological control agent of $M$. vitrata. However, mechanisms that underlie some attributes namely the competitive ability of the wasp remain unclear. Further research should address these mechanisms in order to better appreciate the competitive ability of A. taragamae.

Acknowledgments We thank the Netherlands Universities' Foundation for International Cooperation (NUFFIC) for financially supporting this work through the Netherlands Fellowship Programmes (NFP). We also thank Cyriaque Agboton, Mathias Azokpota, Pascal Agountchémè, Judith Glèlè, Séraphin Eteka, Bernard Hettin, and Basile Dato of the International Institute of Tropical Agriculture (IITA), Benin Station, for their technical assistance with this study.

Open Access This article is distributed under the terms of the Creative Commons Attribution Noncommercial License which permits any noncommercial use, distribution, and reproduction in any medium, provided the original author(s) and source are credited.

\section{References}

Arodokoun DY, Tamò M, Cloutier C, Brodeur J (2006) Larval parasitoids occurring on Maruca vitrata Fabricius 
(Lepidoptera: Pyralidae) in Benin, West Africa. Agr Ecosyst Environ 113:320-325

Babendreier D, Kuske S, Bigler F (2003) Non-target host acceptance and parasitism by Trichogramma brassicae Bezdenko (Hymenoptera: Trichogrammatidae) in the laboratory. Biol Control 26:128-138

Babendreier D, Bigler F, Kuhlmann U (2005) Methods used to assess non-target effects of invertebrate biological control agents of arthropod pests. BioControl 50:821-870

Benson JF (1973) Intraspecific competition in the population dynamics of Bracon hebetor Say (Hymenoptera: Braconidae). J Anim Ecol 42:105-124

Birch LC (1957) The meanings of competition. Am Nat 91:5-18

Boivin G, Brodeur J (2006) Intra- and interspecific interactions among parasitoids: mechanisms, outcomes and biological control. In: Brodeur J, Boivin G (eds) Trophic and guild interactions in biological control. Springer, New York, pp 123-144

Chan MS, Godfray HCJ (1993) Host feeding strategies of parasitoid wasps. Evol Ecol 7:593-604

Collier TR, Hunter MS (2001) Lethal interference competition in the whitefly parasitoids Eretmocerus eremicus and Encarcia sophia. Oecologia 129:147-154

Collier T, Kelly S, Hunter M (2002) Egg size, intrinsic competition and lethal interference in the parasitoids Encarcia pergandiella and Encarsia formosa. Biol Control 23:254-261

Dannon EA, Tamò M, van Huis A, Dicke M (2010a) Functional response and life history parameters of Apanteles, a larval parasitoid of Maruca vitrata. BioControl 55:363-378

Dannon EA, Tamò M, van Huis A, Dicke M (2010b) Effects of volatiles from Maruca vitrata larvae and caterpillarinfested flowers of their host plant Vigna unguiculata on the foraging behaviour of the parasitoid Apanteles taragamae. J Chem Ecol 36:1083-1091

de Moraes CM, Mescher MC (2005) Intrinsic competition between larval parasitoids with different degrees of host specificity. Ecol Entomol 30:564-570

de Moraes C, Cortesero AM, Stapel JO, Lewis WJ (1999) Intrinsic and extrinsic competitive interactions between two larval parasitoids of Heliothis virescens. Ecol Entomol 24:402-410

Fellowes MDE, van Alphen JJM, Jervis MA (2005) Foraging behaviour. In: Jervis MA (ed) Insects as natural enemies, a practical perspective. Cardiff University, Wales, pp 1-71

Fisher RC (1961) A study in insect multiparasitism II. The mechanism and control of competition for possession of the host. J Exp Biol 38:605-608

Hagstrum DW, Smittle BJ (1978) Host utilization by Bracon hebetor. Environ Entomol 7:596-600

Haye T, Goulet H, Mason PG, Kuhlmann U (2005) Does fundamental host range match ecological host range? A retrospective case study of a Lygus plant bug parasitoid. Biol Control 35:55-67

Henneman ML, Memmott J (2001) Infiltration of a Hawaiian community by introduced biological control agents. Science 293:1314-1316

Huang C-C, Peng W-K, Talekar NS (2003) Parasitoids and other natural enemies of Maruca vitrata feeding on Sesbania cannabina in Taiwan. BioControl 48:407-416
Jackai LEN, Raulston JR (1988) Rearing the legume pod borer, Maruca testulalis Geyer (Lepidoptera: Pyralidae) on artificial diet. Trop Pest Manag 34:168-172

Jervis MA, Kidd NA (1986) Host-feeding strategies in Hymenopteran parasitoids. Biol Rev 61:395-434

Křivan V (1997) Dynamic consequences of optimal host feeding on host-parasitoid population dynamics. Bull Math Biol 59:809-831

Kuhlmann U, Schaffner U, Mason PG (2006) Selection of nontarget species for host specificity testing. In: Bigler F, Babendreier D, Kuhlmann U (eds) Environmental impact of invertebrates for biological control of arthropods. CABI International, Wallingford, pp 15-37

Laing JE, Corrigan JE (1987) Intrinsic competition between the gregarious parasite Cotesia glomeratus and the solitary parasite, Cotesia rubecula (Hymenoptera: Braconidae) for their host, Artogeia rapae (Lepidoptera: Pieridae). Entomophaga 32:493-501

Louda SM, Pemberton RW, Johnson MT, Follett PA (2003) Nontarget effects-The Achilles'Heel of biological control? Retrospective analyses to reduce risk associated with biological introductions. Annu Rev Entomol 48:365-396

McBrien H, Mackauer M (1990) Heterospecific larval competition and host discrimination in two species of aphid parasitoids: Aphidius ervi and Aphidius smithi. Entomol Exp Appl 56:145-153

Mohan C, Sathiamma B (2007) Potential for lab rearing of Apanteles taragamae the larval endoparasitoid of coconut pest Opisina arenosella, on the rice moth Corcyra cephalonica. BioControl 52:747-752

Muturi JJ, Ngi-Song AJ, Mueke JM, Setamou M, Schulthess F, Jiang N (2006) Multiparasitism by the pupal parasitoids Xanthopimpla stemmator (Hymenoptera: Ichneumonidae) and Pediobius furvus (Hymenoptera: Eulophidae) on two African cereal stemborers, Chilo partellus (Lepidoptera: Crambidae) and Busseola fusca (Lepidoptera: Noctuidae). Biocontrol Sci Tech 16:49-60

Ngi-Song AJ, Overholt WA, Smith JW Jr, Vinson SB (1999) Suitability of new and old association hosts for the development of selected microgastrine parasitoid of gramineous stemborers. Entomol Exp Appl 90:257-266

Ngi-Song AJ, Kimani-Njogu S, Overholt WA (2001) Multiple parasitism by Cotesia sesamiae and Cotesia flavipes (Hymenoptera: Braconidae) on Busseola fusca (Lepidoptera: Noctuidae). Biocontrol Sci Tech 11:381-390

Odebiyi JA (1982) Parasites of the cotton leafroller, Sylepta derogata (F) (Lepidoptera: Pyralidae) in South Western Nigeria. Bull Entomol Res 72:329-333

Parry D (2009) Beyond Pandora Box: quantitatively evaluating non-target effects of parasitoids in classical biological control. Biol Invasions 11:47-58

Pérez-Lachaud G, Hardy ICW, Lachaud J-P (2002) Insect gladiators: competitive interactions between three species of bethylid wasps attacking the coffee berry borer, $\mathrm{Hy}$ pothenemus hampei (Coleoptera: Scolytidae). Biol Control 25:231-238

Peter C, David BV (1992) Biology of Apanteles taragamae Viereck (Hymenoptera: Braconidae) a parasitoid of $\mathrm{Di}$ aphania indica (Saunders) (Lepidoptera: Pyralidae). Insect Sci Appl 13:7-17 
Pijls JWAM, Hofker KD, van Staalduinen MJ, van Alphen JJM (1995) Interspecific host discrimination and competition in Apoanagyrus (Epidinocarsis) lopezi and $A$ (E.) diversicornis, parasitoids of the cassava mealybug Phenacoccus manihoti. Ecol Entomol 20:326-332

Stiling P, Cornellissen T (2005) What makes a successful biocontrol agent? A meta-analysis of biological control agent performance. Biol Control 34:236-246

Symondson WOC, Sunderland KD, Greenstone MH (2002) Can generalist predators be effective biocontrol agent? Annu Rev Entomol 47:561-594

Tamò M, Arodokoun DY, Zenz N, Tindo M, Agboton C, Adeoti R (2002) The importance of alternative host plants for the biological control of two key cowpea insect pests, the pod borer Maruca vitrata (Fabricius) and the flower thrips Megalurothrips sjosdeti (Trybom). In: Fatokun CA, Tarwali SA, Singh BB, Kormawa PM, Tamò M (eds) Chalenges and opportunities for enhancing sustainable cowpea production, Proceedings of the world cowpea conference III held at the International Institute of Tropical Agriculture (IITA), Ibadan, Nigeria, 4-8 September 2000. IITA-Ibadan, Nigeria, pp 81-93

van Lenteren JC, Babendreier D, Bigler F, Burgio G, Hokkanen HMT, Kuske S, Loomans AJM, Menzler-Hokkanen I, van Rijn PCJ, Thomas MB, Tommasini MG, Zeng QQ (2003) Environmental risk assessment of exotic natural enemies used in inundative biological control. BioControl 48:3-38

van Lenteren JC, Bale J, Bigler F, Hokkanen HMT, Loomans AJM (2006) Assessing risks of releasing exotic biological control agents of arthropod pests. Annu Rev Entomol 51:609-634

Vinson SB, Iwantsch GF (1980) Host suitability for insect parasitoids. Annu Rev Entomol 25:397-419

Yamamoto D, Henderson R, Corley LS, Iwabuchi K (2007) Intrinsic, interspecific competition between egg, egg-larval, and larval parasitoids of plusiine loopers. Ecol Entomol 32:221-228

\section{Author Biographies}

Elie Ayitondji Dannon is an agricultural entomologist who received his $\mathrm{PhD}$ degree in 2011 from Wageningen University on a thesis entitled "Biology and Ecology of Apanteles taragamae, a larval parasitoid of the cowpea pod borer Maruca vitrata". The research was carried out at the Benin station of the International Institute of Tropical Agriculture. This paper is part of his $\mathrm{PhD}$ thesis. His supervisors were Manuele Tamò, Arnold van Huis and Marcel Dicke. He is currently employed as research associate by the University of Abomey-Calavi.

Manuele Tamò is an insect ecologist at the International Institute of Tropical Agriculture (IITA) in Benin. His current research is focusing on the development and deployment of biological control and habitat management options against major insect pests in cereal-legume systems. He has been involved in several regional IPM projects, by which he has established extensive links with colleague scientists and extension agents in 11 African countries.

Arnold van Huis is a tropical entomologist. He has a personal chair at the Laboratory of Entomology of Wageningen University. His main research interests comprise Integrated Pest Management, transdisciplinary science and entomophagy. He coordinates a large research programme that focusses on strengthening agricultural innovation systems in Benin, Ghana and Mali.

Marcel Dicke is an ecologist. He is professor of Entomology and chair of the Laboratory of Entomology of Wageningen University. His research focusses on unravelling the ecology of interactions between plants and insects in a community context by combining ecological studies at population and community levels with investigations of the underlying mechanisms at the subcellular and individual levels. 